\title{
Quality of soybean seeds in response to nitrogen fertilization and inoculation with Bradyrhizobium japonicum ${ }^{1}$
}

\author{
Alan Mario Zuffo ${ }^{2}$, Fábio Steiner ${ }^{3}$, Aécio Busch ${ }^{3}$, Joacir Mario Zuffo Júnior ${ }^{4}$, \\ Alan Eduardo Seglin Mendes ${ }^{5}$, Natália Trajano de Oliveira ${ }^{5}$, Everton Vinicius Zambiazzi ${ }^{5}$
}

\section{ABSTRACT}

Nitrogen fertilization may interfere in the quality of soybean seeds. This study aimed to determine the physiological and sanitary quality of soybean seeds, in response to levels and times of nitrogen $(\mathrm{N})$ application associated with Bradyrhizobium japonicum inoculation. Treatments were arranged in a randomized block design, in a $2 \times 3 \times 4$ factorial arrangement [two soybean cultivars (BRS 1074 IPRO and ST 797 IPRO), three application times (sowing, 30 and 50 days after emergence) and four $\mathrm{N}$ levels $\left(0 \mathrm{~kg} \mathrm{ha}^{-1}, 20 \mathrm{~kg} \mathrm{ha}^{-1}, 40 \mathrm{~kg} \mathrm{ha}^{-1}\right.$ and $\left.60 \mathrm{~kg} \mathrm{ha}^{-1}\right)$, with four replicates. The 1,000-seed mass, moisture content, germination rate, seedling height, shoot length, primary root length, total seedling dry matter, electrical conductivity, mechanical damage, vigor and viability (tetrazolium test) and sanitary quality of the seeds were measured. The use of mineral N, associated with the inoculation of $B$. japonicum bacteria, does not prove to be consistent, in terms of its effects on the physiological quality of soybean seeds, although the incidence of pathogens may be reduced.

KEYWORDS: Glycine max L. Merrill; biological nitrogen fixation; pathogens; seed health.

\section{INTRODUCTION}

Soybean [Glycine $\max$ (L.) Merrill.] is one of the most important oilseed crops in the world, with Brazil being one of the largest producers and occupying an important position in the agricultural economy. In the $2017 / 2018$ growing season, the soybean production area was 35.2 million hectares,

\section{RESUMO}

Qualidade de sementes de soja em resposta à adubação nitrogenada e inoculação de Bradyrhizobium japonicum

A adubação nitrogenada pode interferir na qualidade das sementes de soja. Objetivou-se determinar a qualidade fisiológica e sanitária de sementes de soja, em resposta a doses e épocas de aplicação de nitrogênio $(\mathrm{N})$ associada à inoculação com Bradyrhizobium japonicum. O delineamento experimental utilizado foi o de blocos casualizados, disposto em esquema fatorial 2 × 3 × 4 [duas cultivares de soja (BRS 1074 IPRO e ST 797 IPRO), três épocas de aplicação (semeadura, 30 e 50 dias após a emergência $)$ e quatro doses de nitrogênio $\left(0 \mathrm{~kg} \mathrm{ha}^{-1}, 20 \mathrm{~kg} \mathrm{ha}^{-1}\right.$, $40 \mathrm{~kg} \mathrm{ha}^{-1}$ e $\left.60 \mathrm{~kg} \mathrm{ha}^{-1}\right)$ ], com quatro repetições. Determinou-se a massa de 1.000 sementes, grau de umidade, germinação, altura de plântula, comprimento da radícula, fitomassa seca total da plântula, emergência, condutividade elétrica, dano mecânico, vigor e viabilidade (teste de tetrazólio) e a qualidade sanitária das sementes. $\mathrm{O}$ uso de $\mathrm{N}$ mineral, associado à inoculação de bactérias Bradyrhizobium japonicum, não se mostra consistente, quanto aos seus efeitos sobre a qualidade fisiológica das sementes de soja, embora a incidência de patógenos possa ser reduzida.

PALAVRAS-CHAVE: Glycine max L. Merrill; fixação biológica de nitrogênio; patógenos; sanidade de sementes.

resulting in 119.0 million tons of grains (Conab 2018). Due to its economic importance, it is crucial that soybean seed growers produce high-quality seeds to ensure more vigorous seedlings and the successful establishment of plants in the field (Zuffo et al. 2017a).

In seed production fields, the use of fertilizers is more common than in grain production fields.

1. Manuscript received in Feb./2018 and accepted for publication in Aug./2018 (http://dx.doi.org/10.1590/1983-40632018v4851638).

2. Universidade Federal de Mato Grosso do Sul, Departamento de Agronomia, Chapadão do Sul, MS, Brasil.

E-mail/ORCID: alan_zuffo@hotmail.com/0000-0001-9704-5325.

3. Universidade Estadual de Mato Grosso do Sul, Departamento de Agronomia, Cassilândia, MS, Brasil.

E-mail/ORCID: steiner@uems.br/0000-0001-9091-1737,busch088@gmail.com/0000-0002-9788-250X.

4. Universidade do Estado de Mato Grosso, Departamento de Agronomia, Nova Xavantina, MT, Brasil. E-mail/ORCID: zuffojr@gmail.com/0000-0001-7671-2096.

5. Universidade Federal de Lavras, Departamento de Agricultura, Lavras, MG, Brasil.

E-mail/ORCID: eduseglin@hotmail.com/0000-0002-6276-1193, nataliatrajano@bol.com.br/0000-0002-5562-0157, everton_zambiazzi@hotmail.com/0000-0002-4598-9129. 
This is because the adequate supply of nutrients to the plants is essential for the embryo formation and the reserve organs (Carvalho \& Nakagawa 2012), thus obtaining high-quality seeds (Toledo et al. 2009, Abrantes et al. 2010). According to Sediyama (2013), the quality of soybean seeds is influenced by the genetic constitution, agronomic practices and environmental factors, from the seed formation to storage. However, there is little information available on plant nutrition relating to the production of soybean seeds. In view of this, fertilization is conducted based on the established recommendations for grain yield (Carvalho \& Nakagawa 2012) and, among the nutrients, nitrogen $(\mathrm{N})$ stands out.

Nitrogen is a fundamental constituent of all proteins and several other organic compounds of the plant, and, therefore, it can affect the seed physiological and sanitary quality (Abrantes et al. 2010). Under Brazilian tropical conditions, the soybean $\mathrm{N}$ requirement is generally fulfilled by biological nitrogen fixation, through the symbiosis with Bradyrhizobium sp. (Domingos et al. 2015). However, as the process of symbiotic $\mathrm{N}$ fixation has a large energy cost for plants, some studies showed an increase in the grain yield, when $\mathrm{N}$ was added through mineral fertilization (Caliskan et al. 2008). The current recommendation for the soybean grain production is the use of inoculant containing Bradyrhizobium strains without the addition of $\mathrm{N}$ fertilizer, or up to the rate of $20 \mathrm{~kg} \mathrm{ha}^{-1}$ of $\mathrm{N}$ at sowing, when the soil has a low organic matter content (Embrapa 2013). When soybean is grown in soils where $\mathrm{N}$ is deficient, the application of low $\mathrm{N}$ rates at sowing has been used as a starter fertilization, to compensate the lack of synchronism between the phase when seed $\mathrm{N}$ reserves are exhausted and the moment when plants begin to benefit from the $\mathrm{N}$ fixed by the bacteria (Embrapa 2013, Chibeba et al. 2015). In turn, larger rates have been shown to negatively affect the nodulation process (Kaschuk et al. 2016) and growth of soybean plants (McCoy et al. 2018). However, the impact of the use of chemical $\mathrm{N}$ fertilizer on the nitrogen fixation and crop yield depends on the soybean cultivar and Bradyrhizobium strain, as well as on the amount and time of $\mathrm{N}$ application (Domingos et al. 2015).

Some studies have reported that the use of $\mathrm{N}$ fertilizers does not improve the productive performance of the crop (Aratani et al. 2008, Kaschuk et al. 2016). In contrast, other research studies have shown that $\mathrm{N}$ fertilization can improve the soybean plant growth and grain yield (Barranqueiro \& Dalchiavon 2017, Moreno et al. 2018). However, there are no studies that have evaluated the $\mathrm{N}$ fertilizer application in soybean and the physiological and sanitary quality of the seeds. It is known that $\mathrm{N}$ may influence the physiological quality of seeds, but the effects vary, depending on the environmental conditions and plant development stage during which the fertilizer application occurs (Carvalho \& Nakagawa 2012).

In view of this, it is considered relevant to investigate this subject, involving not only the physiological aspects, but also the sanitary quality of seeds. Thus, this study aimed to determine the physiological and sanitary quality of soybean seeds, in response to levels and times of $\mathrm{N}$ fertilizer application, associated with Bradyrhizobium japonicum inoculation.

\section{MATERIAL AND METHODS}

The experiment was carried out at an experimental area of the Universidade Estadual de Mato Grosso do Sul, in Cassilândia, Mato Grosso

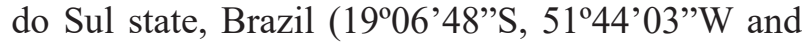
altitude of $470 \mathrm{~m}$ ), from December 2016 to March 2017. The regional climate, according to the Köppen classification, is Aw, characterized as tropical, with hot summers and a tendency toward high rainfall levels, and dry winters, with a dry season between May and September. The environmental conditions during the experiment included an average air temperature of $27^{\circ} \mathrm{C}$ and a total rainfall of $1,132 \mathrm{~mm}$.

The soil was classified as an Arenic Entisol, with $95 \mathrm{~g} \mathrm{~kg}^{-1}$ of clay, $50 \mathrm{~g} \mathrm{~kg}^{-1}$ of silt and $855 \mathrm{~g} \mathrm{~kg}^{-1}$ of sand. Prior to this experiment, the area had no known history of Bradyrhizobium inoculation and had been occupied by Urochloa sp. pasture, without any fertilization, for twelve years. Soils associated with the first soybean cropping are considered ideal for testing the interaction between the Bradyrhizobiumsoybean symbiosis and $\mathrm{N}$ fertilizer application. Before starting the experiment, the soil was sampled at the $0-0.20 \mathrm{~m}$ layer. The main chemical properties were as it follows: $\mathrm{pH}$ in $\mathrm{CaCl}_{2}$ of $5.6 ; 14 \mathrm{~g} \mathrm{~kg}^{-1}$ of organic matter; $8.3 \mathrm{mg} \mathrm{dm}^{-3}$ of $\mathrm{P}\left(\right.$ Mehlich $\left.^{-1}\right) ; 0.07 \mathrm{cmol}_{\mathrm{c}} \mathrm{dm}^{-3}$ of $\mathrm{K}^{+} ; 2 \mathrm{cmol}_{\mathrm{c}} \mathrm{dm}^{-3}$ of $\mathrm{Ca}^{2+} ; 0.7 \mathrm{cmol}_{\mathrm{c}} \mathrm{dm}^{-3}$ of $\mathrm{Mg}^{2+}$; $0 \mathrm{cmol}_{\mathrm{c}} \mathrm{dm}^{-3}$ of $\mathrm{Al}^{3+} ; 2 \mathrm{cmol}_{\mathrm{c}} \mathrm{dm}^{-3}$ of $\mathrm{H}^{+}+\mathrm{Al}^{3+}$; $4.77 \mathrm{cmol}_{\mathrm{c}} \mathrm{dm}^{-3}$ of CEC; $58 \%$ of base saturation; 
$18.2 \mathrm{mg} \mathrm{dm}^{-3}$ of $\mathrm{S}_{-} \mathrm{SO}_{4}^{2-} ; 0.45 \mathrm{mg} \mathrm{dm}{ }^{-3}$ of $\mathrm{B}$; $0.9 \mathrm{mg} \mathrm{dm}^{-3}$ of $\mathrm{Cu}^{2+} ; 32 \mathrm{mg} \mathrm{dm}^{-3}$ of $\mathrm{Fe}^{2+} ; 76.8 \mathrm{mg} \mathrm{dm}^{-3}$ of $\mathrm{Mn}^{2+}$; and $12.8 \mathrm{mg} \mathrm{dm}^{-3}$ of $\mathrm{Zn}^{2+}$.

The experiment was arranged in a randomized block design, in a $2 \times 3 \times 4$ factorial scheme, with four replicates. Treatments consisted of two soybean cultivars (BRS 1074 IPRO - indeterminate growth habit, cycle of 108-114 days, maturation group 7.4; and ST 797 IPRO - indeterminate growth habit, cycle of 120-130 days, maturity group 7.9), three application times (sowing, 30 and 50 days after emergence - DAE) and four nitrogen levels $\left(0 \mathrm{~kg} \mathrm{ha}^{-1}\right.$, $20 \mathrm{~kg} \mathrm{ha}^{-1}, 40 \mathrm{~kg} \mathrm{ha}^{-1}$ and $\left.60 \mathrm{~kg} \mathrm{ha}^{-1}\right)$. The source of $\mathrm{N}$ used was urea ( $45 \%$ of $\mathrm{N}$ ). The $\mathrm{N}$ application levels used in this study were based on the recommended rate $\left(20 \mathrm{~kg} \mathrm{ha}^{-1}\right)$ for soybean grain production (Embrapa 2013). Therefore, as the soybean production fields require a higher nutritional demand, rates higher than $20 \mathrm{~kg} \mathrm{ha}^{-1}$ of N, in association with Bradyrhizobium sp. inoculation, were applied, with the purpose of obtaining soybean seeds of better physiological and sanitary quality. The experimental units consisted of eight $5.0-\mathrm{m}$ long rows, with $0.50 \mathrm{~m}$ between-row spacing. The useful area comprised the four central rows of each plot, disregarding $0.50 \mathrm{~m}$ of each edge.

Soybean seeds previously treated with pyraclostrobin + methyl thiophanate + fipronil (Standak Top ${ }^{\circledR}$ ) were inoculated with Bradyrhizobium japonicum, using the commercial product Simbiose Nod Soja ${ }^{\circledR}$ (Simbiose: Biological Agrotechnology), with a liquid formulation containing SEMIA 5079 and SEMIA 5080 strains (minimum concentration of $7.2 \times 10^{9}$ viable cells $\left.\mathrm{mL}^{-1}\right)$, at a rate of $3 \mathrm{~mL} \mathrm{~kg}^{-1}$ of seeds. The amount of inoculant used was dissolved in a solution containing $2 \mathrm{~mL} \mathrm{~kg}^{-1}$ of additive for inoculant Protege ${ }^{\circledR}$ TS (Total Biotechnology) and, then, both products (inoculant + additive) were applied to the seeds. The inoculant additive consists of active metabolites of bacteria, sugar complex and encapsulating biopolymers, and has the purpose of improving the protection and viability of the bacteria on the seeds. To potentiate the soybean nodulation, the seeds were also subjected to an application of micronutrients, especially molybdenum. The source used was the commercial seed fertilizer Nódulus ${ }^{\circledR}$ Premium 125 (Biosoja), containing $10 \%$ of Mo, $1 \%$ of $\mathrm{Co}, 1 \%$ of S, $1 \%$ of $\mathrm{Ca}$ and $0.2 \%$ of Fe. In this study, all treatments were inoculated with elite strains of Bradyrhizobium japonicum, since it is a well-established and effective practice for the soybean production in tropical areas. Currently, all Brazilian soybean producers adopt the inoculation of Bradyrhizobium sp. as the main source of $\mathrm{N}$ for the plants, since it is an efficient practice, with a low economic cost, when compared to the use of chemical $\mathrm{N}$ fertilizer.

Soybean seeds were sown manually on 15 December 2016, in rows of $0.50 \mathrm{~m}$ apart, at a density of 15 seeds $\mathrm{m}^{-1}$. Base fertilization was carried out by applying $120 \mathrm{~kg} \mathrm{ha}^{-1}$ of $\mathrm{P}_{2} \mathrm{O}_{5}$ (simple superphosphate) and $90 \mathrm{~kg} \mathrm{ha}^{-1}$ of $\mathrm{K}_{2} \mathrm{O}$ (potassium chloride). Potassium fertilization was split into two applications: one at sowing and one at $30 \mathrm{DAE}$.

The management of weeds, pests and diseases was carried out according to the requirements for the crop and technical recommendations. During the plant development, the management of weeds, pests and diseases was performed using glyphosate, pyraclostrobin + epoxiconazole, azoxystrobin + cyproconazole, teflubenzurom, chlorpyrifos and cypermethrin.

The soybean harvest was performed manually in the $\mathrm{R}_{8}$ phenological stage (when $95 \%$ of the pods have the typical coloration of mature pods). After harvest, plants were air-dried at room temperature, for $48 \mathrm{~h}$, and then the seeds were extracted by hand and passed through sieves with round holes (hole diameter of $5.5 \mathrm{~mm}$ ). After cleaning the seeds, the 1,000-seed weight was determined (Brasil 2009), with correction for a $13 \%$ wet basis. A seed sample of approximately $800 \mathrm{~g}$ was prepared for each field plot, packed in Kraft-type paper bags, and then kept in the laboratory at a temperature of $25 \pm 0.8^{\circ} \mathrm{C}$, for four months. Afterwards, the physiological quality of the seeds was evaluated, using the following tests:

- Water content: after drying in the shade, the water content $(\%)$ of seeds was determined by the oven drying method at $105^{\circ} \mathrm{C}\left( \pm 3{ }^{\circ} \mathrm{C}\right)$, for $24 \mathrm{~h}$ (Brasil 2009);

- Germination test: four replicates of 50 seeds were evenly distributed among three sheets of paper towel moistened with distilled water at the proportion of 2.5 times the mass of the dry substrate. The paper towel sheets were then turned into rolls, which were packaged into plastic bags, to prevent evaporation and maintain the relative humidity close to $100 \%$. Germination was carried out in a growth chamber under a 12/12 h photoperiod (light/darkness) and at a temperature of $25{ }^{\circ} \mathrm{C}$. Germinated seeds were recorded at 8 days after starting the test (Brasil 2009); 
- Shoot and root length: the shoot and primary root length were measured in ten normal seedlings, randomly collected after the germination test (eight days), using a meter scale, and the results were expressed in $\mathrm{cm}$;

- Emergence test: the seedling emergence test was carried out in a greenhouse, using four 50 -seed replicates for each treatment. The seeds were placed in plastic trays $(42 \mathrm{~cm} \times 28 \mathrm{~cm} \times 6 \mathrm{~cm})$ to germinate, containing soil and sand at a proportion of 2:1 (v/v). The moisture content of the substrate was maintained at $70 \%$ of the field capacity with daily irrigation. The trays were kept in a greenhouse at $25{ }^{\circ} \mathrm{C}\left( \pm 2{ }^{\circ} \mathrm{C}\right)$. Seedling counts were performed daily until the end of the fourteenth day, and the final emergence percentage (\%) was then determined;

- Plant dry matter: for determining the dry matter accumulation of shoots and roots, all seedlings obtained at the end of the seedling emergence test (fourteenth day) were collected, dried in an oven at $60{ }^{\circ} \mathrm{C}$, for three days, and then weighed. The results were expressed as mg seedling ${ }^{-1}$;

- Electrical conductivity: four replicates of 50 seeds for each treatment were placed in $300 \mathrm{~mL}$ plastic cups and weighed on an analytical scale (0.001 g accuracy). Distilled water $(75 \mathrm{~mL})$ was then added to each container. The containers were placed in a biological oxygen demand (BOD) incubator at a constant temperature of $25^{\circ} \mathrm{C}$, for $24 \mathrm{~h}$ (Krzyzanowski et al. 1999). Seeds were then gently agitated for the homogenization of the solution, and the electrical conductivity was measured with a conductivity meter (MS TECNOPON ${ }^{\circledR}$ - mCA150). The results were expressed as $\mu \mathrm{S} \mathrm{cm}^{-1} \mathrm{~g}^{-1}$;

- Tetrazolium test: the test was conducted with two sub-samples of 50 seeds per treatment. The pre-conditioning of the seeds was carried out on the moist germination paper towel for $16 \mathrm{~h}$, at $25{ }^{\circ} \mathrm{C}$. Afterwards, the seeds were transferred to plastic cups with a $0.075 \%$ solution of 2,3,5-triphenyl tetrazolium chloride and stained in a dark chamber at $40^{\circ} \mathrm{C}$, for $3 \mathrm{~h}$. The seeds were then washed in running water and each seed was individually examined to determine the location and extent of external and internal damage (mechanical damage, weathering and stink bug feeding damage) by cutting longitudinally along the embryonic axis and removing the seed coat (França-Neto et al. 1998);

- Seed sanitary quality: the evaluation of the sanitary quality of soybean seeds was performed based on the Blotter-test method, according to Machado (2000), with modifications. Five replicates of 40 seeds were placed in Petri dishes and incubated for 7 days, under a photoperiod of $12 \mathrm{~h}$ of light and temperature of $20 \pm 2{ }^{\circ} \mathrm{C}$, and then evaluated for the presence of pathogens associated with the seeds. Seed health was evaluated through the confidence interval for proportions $(P)$, using the Poisson approximation at $5 \%$ of significance (Ramalho et al. 2012).

Data were submitted to analysis of variance (Anova) and, when significant, the means were compared by the Least Significant Differences (LSD) test at $5 \%$ of probability. Regression analysis was used for the $\mathrm{N}$ fertilizer levels, and significant equations (F-test; $p \leq 0.05$ ) with the highest coefficients of determination were adjusted. For the statistical analysis, the data expressed as percentage were previously transformed into arcsin values $(\mathrm{x} / 100)^{0.5}$. All analyses were performed using the Sisvar ${ }^{\circledR}$ software, version 5.6 for Windows (Statistical Analysis Software, UFLa, Lavras, MG, Brasil).

\section{RESULTS AND DISCUSSION}

The results of the analysis of variance did not show significant effects $(p>0.05)$ for the interaction among the tested factors (cultivar, application time and $\mathrm{N}$ level) for any of the traits measured. Therefore, the results are presented separately for the main effects of cultivar, application time and $\mathrm{N}$ level. The absence of significant interaction among the studied factors indicates that the soybean cultivars have a similar response to the different levels and times of the $\mathrm{N}$ fertilizer application.

The results showed significant effects among soybean cultivars for the variables seed germination, shoot length, primary root length, seedling dry matter, electrical conductivity and vigor (tetrazolium test) (Table 1). The effect of cultivars on the physiological quality of soybean seeds was also verified by Zambiazzi et al. (2014) and Zuffo et al. (2016). These variations are related to differences in the genetic potential, growth habit and other intrinsic characteristics of each cultivar (Felisberto et al. 2015, Soares et al. 2015).

In general, soybean seeds of the ST 797 IPRO cultivar had a higher physiological quality and seedling vigor, indicated by the higher germination rate, shoot length, primary root length, total dry matter, 
Table 1. Effects of $\mathrm{N}$ fertilizer application times in two soybean cultivars on the 1,000-seed weight (1,000-W), water content (WC), germination (GERM), shoot length (SL), primary root length (RL), total dry matter (TDM), emergence (EMER), electrical conductivity $(\mathrm{EC})$, vigor percentage by the tetrazolium test $\left(\mathrm{TT}_{1-3}\right)$ and viability percentage by the tetrazolium test $\left(\mathrm{TT}_{1-5}\right)$.

\begin{tabular}{|c|c|c|c|c|c|c|c|c|c|c|}
\hline \multirow{2}{*}{ Sources of variation } & $1,000-W$ & $\mathrm{WC}$ & GERM & SL & RL & TDM & EMER & EC & $\mathrm{TT}_{1-3}$ & $\mathrm{TT}_{1-5}$ \\
\hline & $\mathrm{g}$ & \multicolumn{2}{|c|}{ 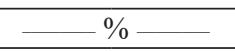 } & \multicolumn{2}{|c|}{$\mathrm{cm}$} & $\mathrm{mg}$ & $\%$ & $\mu \mathrm{S} \mathrm{cm}^{-1} \mathrm{~g}^{-1}$ & \multicolumn{2}{|c|}{$-\%$} \\
\hline Cultivar $^{1}$ & \multicolumn{10}{|c|}{ Mean values } \\
\hline BRS 1074 IPRO & $130.1 \mathrm{a}$ & $7.79 \mathrm{a}$ & $57 \mathrm{~b}$ & $8.00 \mathrm{~b}$ & $13.69 \mathrm{~b}$ & $29.77 b$ & $68 \mathrm{a}$ & $152.5 \mathrm{a}$ & $61 \mathrm{a}$ & $80 \mathrm{~b}$ \\
\hline ST 797 IPRO & $125.5 \mathrm{a}$ & $8.10 \mathrm{a}$ & $62 \mathrm{a}$ & $8.62 \mathrm{a}$ & $14.68 \mathrm{a}$ & $34.63 \mathrm{a}$ & $83 \mathrm{a}$ & $109.6 \mathrm{~b}$ & $64 \mathrm{a}$ & $84 \mathrm{a}$ \\
\hline \multicolumn{11}{|l|}{ Application times ${ }^{2}$} \\
\hline Sowing & $127.5 \mathrm{a}$ & $8.01 \mathrm{a}$ & $48 \mathrm{~b}$ & $8.27 \mathrm{a}$ & $14.26 \mathrm{a}$ & $28.86 \mathrm{c}$ & $73 \mathrm{a}$ & $135.2 \mathrm{a}$ & $64 \mathrm{a}$ & $85 \mathrm{a}$ \\
\hline $30 \mathrm{DAE}$ & $132.4 \mathrm{a}$ & $7.84 \mathrm{a}$ & $65 \mathrm{a}$ & $8.51 \mathrm{a}$ & $13.82 \mathrm{a}$ & $36.55 \mathrm{a}$ & $77 \mathrm{a}$ & $131.3 \mathrm{a}$ & $65 \mathrm{a}$ & $84 \mathrm{a}$ \\
\hline $50 \mathrm{DAE}$ & $123.5 \mathrm{a}$ & $7.99 \mathrm{a}$ & $66 \mathrm{a}$ & $8.15 \mathrm{a}$ & $14.47 \mathrm{a}$ & $31.18 \mathrm{~b}$ & $77 \mathrm{a}$ & $126.6 \mathrm{a}$ & $58 \mathrm{~b}$ & $76 \mathrm{~b}$ \\
\hline CV (\%) & 11.39 & 5.18 & 9.99 & 11.01 & 12.95 & 11.43 & 12.57 & 11.49 & 15.45 & 8.74 \\
\hline
\end{tabular}

${ }^{1}$ Values represented by different letters in the column for the cultivars show significant differences by the $\mathrm{F}$ test, at $5 \%$ of probability. ${ }^{2}$ Values represented by different letters in the column for the $\mathrm{N}$ application times show significant differences by the t-test (LSD), at $5 \%$ of probability. CV: coefficient of variation. DAE: days after emergence.

electrical conductivity and viability percentage by the tetrazolium test (Table 1). Therefore, the difference between cultivars may be related to the characteristics of the genetic material of each one. According to Sediyama (2013), soybean cultivars differ in the chemical composition of the seeds produced.

On the other hand, the $\mathrm{N}$ application times significantly affected the seed germination, total dry matter, vigor percentage $\left(\mathrm{TT}_{1-3}\right)$ and viability percentage $\left(\mathrm{TT}_{1-5}\right)$ by the tetrazolium test (Table 1). The highest germination rate was observed with the $\mathrm{N}$ application at $30 \mathrm{DAE}$ and $50 \mathrm{DAE}$, whereas the highest total dry matter occurred with the $\mathrm{N}$ application at $30 \mathrm{DAE}$. The application of $\mathrm{N}$ at sowing and at $30 \mathrm{DAE}$ resulted in a greater vigor and viability percentage of seeds by the tetrazolium test (Table 1). Toledo et al. (2009) also demonstrated that the application of $\mathrm{N}$ at $22 \mathrm{DAE}$ and $50 \mathrm{DAE}$ resulted in the highest physiological quality of common bean seeds (Phaseolus vulgaris L.). Although the application of $\mathrm{N}$ at $30 \mathrm{DAE}$ provided an increased germination rate, vigor and viability of the seeds, the application levels had little effect on the physiological quality of the seeds (Figure 1). Therefore, the use of mineral $\mathrm{N}$, associated with $B$. japonicum inoculation, was not consistent with its effects on the physiological quality of soybean seeds.

The application levels of $\mathrm{N}$ resulted in a significant effect only on the variables germination, total dry matter and electrical conductivity, with adjustment of quadratic equations. These findings corroborate, in part, those obtained by Toledo et al. (2009), who showed that $\mathrm{N}$ fertilization in common bean resulted in the production of seeds with a higher germination rate.
With regard to the 1,000-seed weight, there was no significant difference among the $\mathrm{N}$ levels (Figure 1a). Opposite results were reported by Petter et al. (2012), who demonstrated that the application of $\mathrm{N}$ significantly influenced the 1,000-seed weight of different soybean cultivars, with an increase in the seed size with the application of $20 \mathrm{~kg} \mathrm{ha}^{-1}$ and $40 \mathrm{~kg} \mathrm{ha}^{-1}$ of $\mathrm{N}$. These authors attributed the increase in seed weight to the higher protein accumulation in the seeds, due to the greater synthesis of amino acids caused by the presence of N. Such differences may be related to the cultivars evaluated in the studies and the maturation cycle.

The water content of seeds from plants fertilized with the different levels of $\mathrm{N}$ did not show significant differences (Figure 1b). According to Loeffler et al. (1998), the uniformity of the water content is of paramount importance to standardize the physiological evaluations of the seeds and to provide consistent results.

In general, the germination percentage was lower than the standard required $(80 \%)$ for the commercialization of soybean seeds in Brazil (Table 1; Figure 1c), according to marketing standards (Brasil 2013). Silva et al. (2017) also reported a low percentage of seed germination (62\%), when evaluating the effect of $\mathrm{N}$ application on the physiological quality of soybean seeds. Seeds with medium or low germination rates produce seedlings with less competitiveness in the field, thus compromising the successful establishment of the plant stand (França-Neto et al. 2010). The low germination rate observed in this study was due to the high percentage of seeds with moisture damage and stink bug feeding damage verified in the tetrazolium 

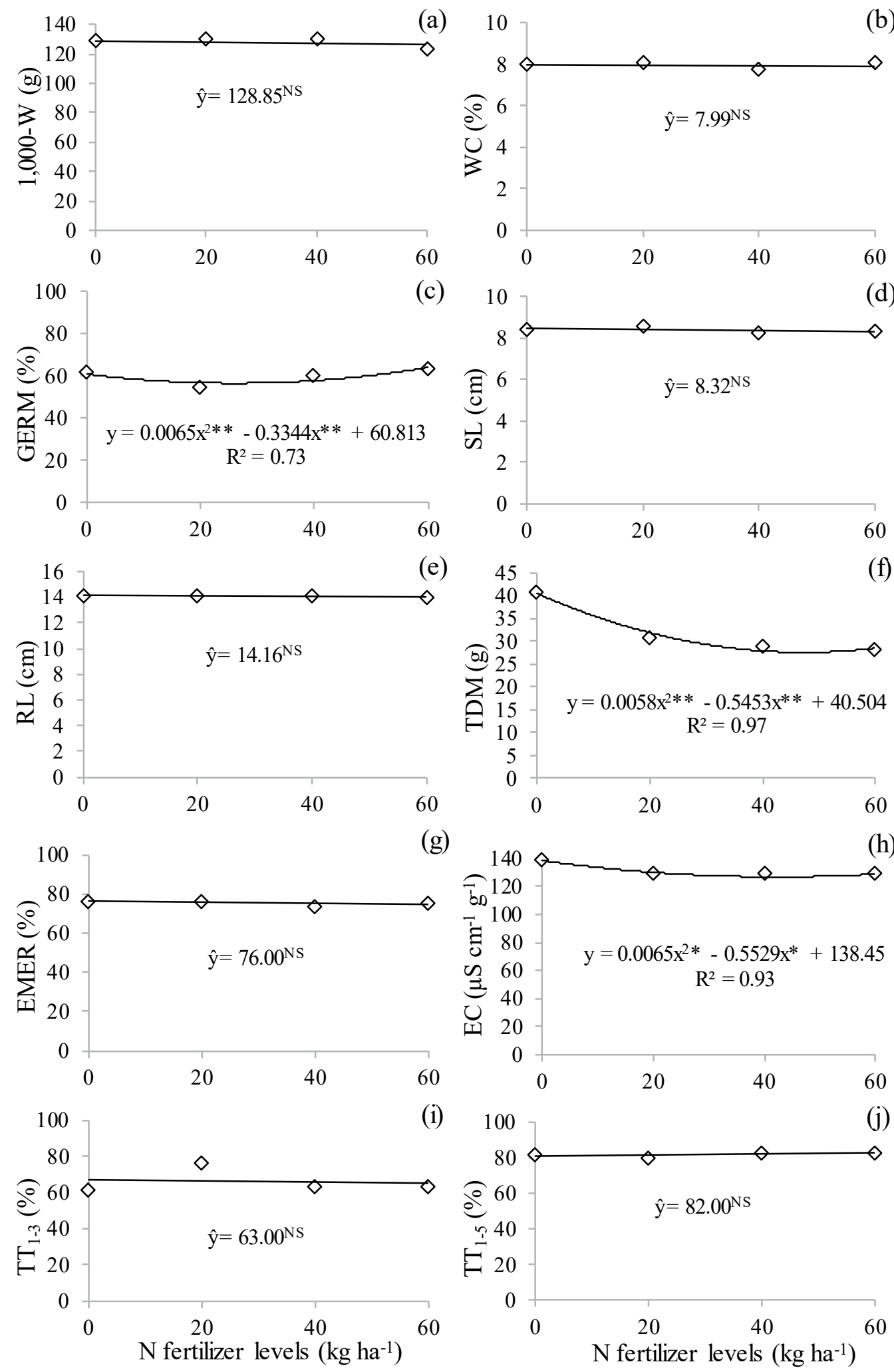

Figure 1. Effects of $\mathrm{N}$ fertilizer application levels on the 1,000-seed weight (1,000-W; a), water content (WC; b), germination rate (GERM; c), shoot length (SL; d), primary root length (RL; e), total dry matter (TDM; f), emergence (EMER; g), electrical conductivity $(\mathrm{EC} ; \mathrm{h})$, vigor percentage by the tetrazolium test $\left(\mathrm{TT}_{1-3} ; \mathrm{i}\right)$ and viability percentage by the tetrazolium test $\left(\mathrm{TT}_{1-5} ; \mathrm{j}\right)$ of the soybean seeds. ** and *: significant at $1 \%$ and $5 \%$ of probability by the $\mathrm{F}$ test, respectively. 
test (Figure 2) and the presence of pathogens (Figure 3). Therefore, the stink bug feeding damage, associated with the high rainfall rate during the maturation period of the soybean, reduced drastically the physiological quality of the seeds. Forti et al. (2010) also showed that the moisture damage in the seeds may affect the quality and physiological potential of soybean seeds. In addition, the authors
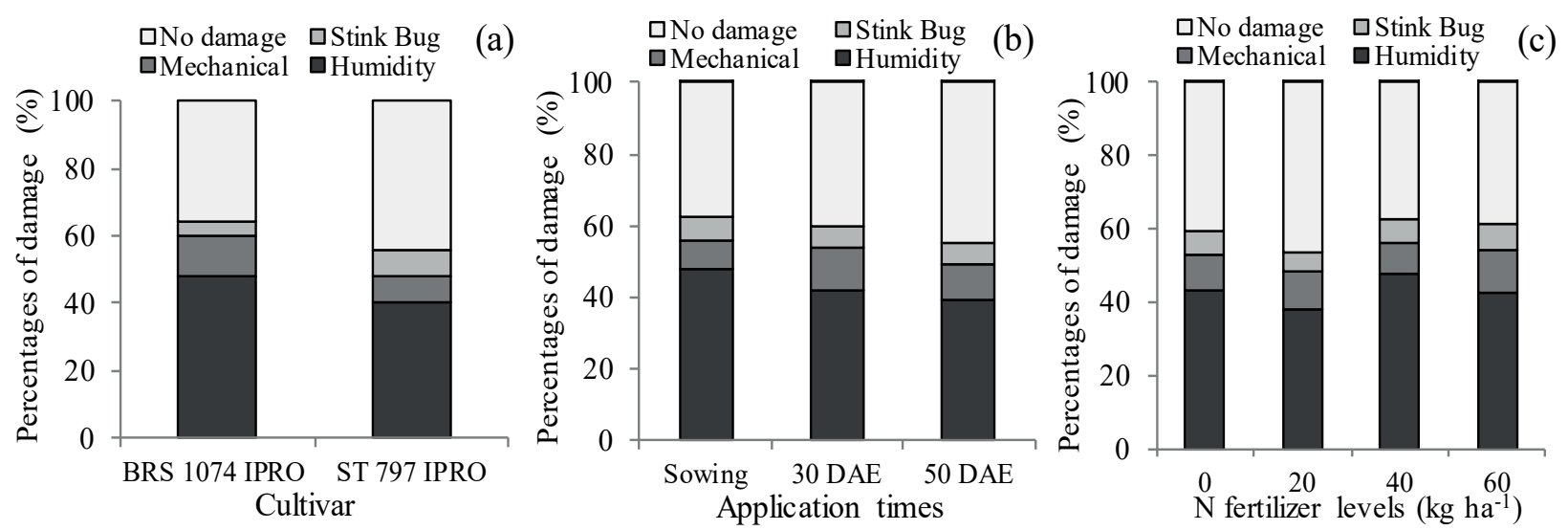

Figure 2. Damage caused and the respective percentages observed in the tetrazolium test for the soybean cultivars (a), $\mathrm{N}$ application times (b) and $\mathrm{N}$ fertilizer levels (c).

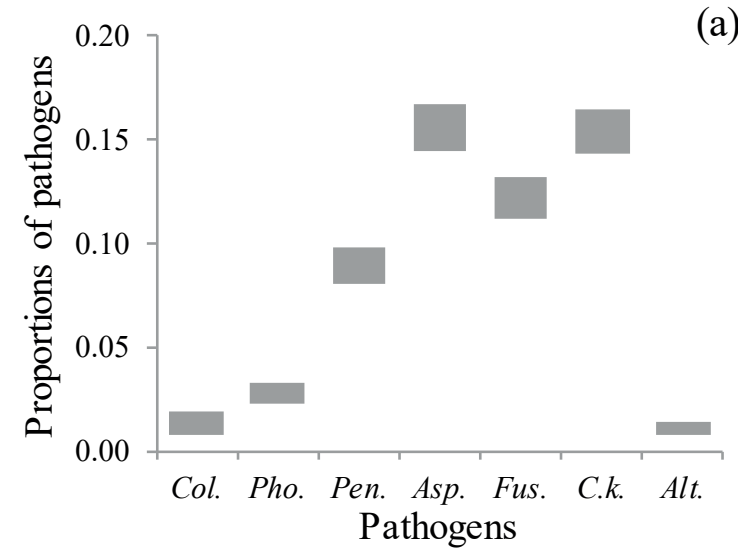

(a)
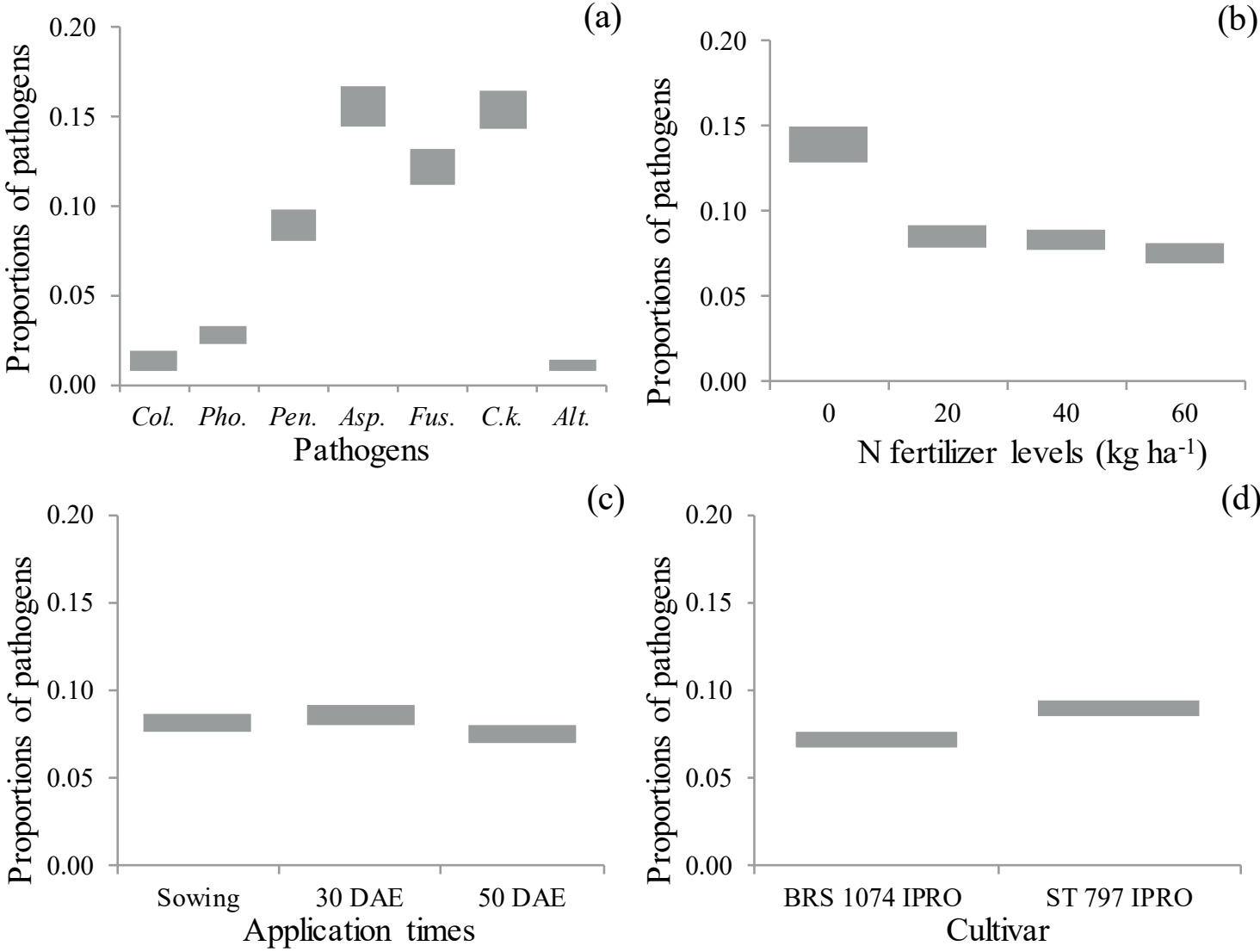

Figure 3. Confidence intervals (95\% of probability) for the proportions of pathogens (Col.: Colletotrichum; Pho.: Phomopsis; Pen.: Penicillium; Asp.: Aspergillus; Fus.: Fusarium; C.k.: Cercospora kikuchii; Alt.: Alternaria) of soybean seeds (a), as affected by $\mathrm{N}$ fertilizer application levels (b), $\mathrm{N}$ application times (c) and two soybean cultivars (d). 
showed that there is an evolution of moisture damage during storage.

With regard to the variables shoot height (Figure 1d), primary root length (Figure 1e), emergence (Figure 1g), vigor percentage by the tetrazolium test (Figure 1i) and viability percentage by the tetrazolium test (Figure 1j), there were no significant differences among the $\mathrm{N}$ application levels. On the other hand, there was a tendency for a reduction in the total dry matter of seedlings with increasing N levels (Figure 1f). Toledo et al. (2009) showed that the $\mathrm{N}$ fertilization of bean crops does not influence the shoot length and dry matter of seedlings from seeds stored for four months.

For the electrical conductivity test (Figure 2b), the treatment involving no $\mathrm{N}$ fertilizer resulted in higher electrical conductivity values, what indicates the lower physiological potential of the seeds. It is important to emphasize that, in soybean seed lots with high vigor, the electrical conductivity values should be, at most, up to $70-80 \mu \mathrm{S} \mathrm{cm}{ }^{-1} \mathrm{~g}^{-1}$ (Krzyzanowski et al. 1999). Therefore, although the treatments that received $\mathrm{N}$ resulted in lower electrical conductivity values, if compared to the control, the values reported for all $\mathrm{N}$ levels showed the low physiological potential of the seeds.

When verifying the damage detected in the tetrazolium test, it is possible to infer that the low physiological quality of the seeds of this study is attributed mainly to moisture damage, followed by mechanical damage and stink bug feeding damage (Figure 2). Therefore, it is evident, for the factors soybean cultivars (Figure 2a), $\mathrm{N}$ application times (Figure 2b) and $\mathrm{N}$ fertilizer levels (Figure 2c), that moisture damage was more relevant for seed deterioration. The highest incidence of moisture damage was related to rainfall during the seed harvest (Figure 1), which probably contributed to the occurrence and subsequent evolution of this type of damage. Castro et al. (2016) reported that oscillations of wet and dry environmental conditions, especially in tropical regions, may cause seed damage. Therefore, a drop in the seed quality is due to damage in the integument, as a consequence of expansion and contraction, after successive wetting and drying cycles (MarcosFilho 2005).

In the sanitary evaluation of the seeds, the pathogens Colletotrichum sp., Phomopsis sp., Penicillium sp., Aspergillus sp., Fusarium sp., Cercospora kikuchii and Alternaria sp. were identified (Figure 3a). Zuffo et al. (2017b), when evaluating the effect of harvest times for the soybean BRS 820 RR $^{\circledR}$ cultivar, in Lavras, Minas Gerais state, Brazil, also demonstrated the incidence of these pathogens. These are pathogens which occur widely and have a great importance in Brazil, causing significant losses in the production and reduction in the quality of soybean seeds (Danelli et al. 2011).

Among the pathogens observed in soybean seeds, Aspergillus sp., Fusarium sp., Cercospora kikuchii and Penicillium sp. stood out, due to their higher incidence (Figure 3a). According to MarcosFilho (2005), the fungus of the Fusarium sp. genus is known as a field fungus, whereas Penicillium sp. and Aspergillus sp. are storage fungi, which contaminate the seeds mainly after harvest.

In general, a higher incidence of pathogens was observed in seeds from plants non-fertilized with $\mathrm{N}$ (Figure 3c). According to Marschner (1995), the use of high $\mathrm{N}$ concentrations affects the production of phenolic compounds and lignification of leaves, thus reducing the resistance to the obligatory pathogens, as well as the $\mathrm{N}$ can increase the concentration of amino acids and amides, which favor the development of fungi. However, this fact was not observed in this study, possibly due to the use of low $\mathrm{N}$ application levels. On the other hand, the pathogen severity may be reduced by an adequate nutrition, as well as increasing the efficiency of the genetic, chemical or biological control of pathogens (Carvalho \& Nakagawa 2012).

The pathogens present in the seeds may increase their deterioration and cause a reduction in seed germination and vigor (Binotti et al. 2008). However, in the present study, there was a lower sanitary quality in soybean seeds from plants that did not receive nitrogen. Thus, it may be considered that, despite the higher incidence of pathogens in the seeds, such conditions did not reduce the physiological quality of soybean seeds.

In general, it was observed that the incidence of pathogens was similar for the different times of $\mathrm{N}$ fertilizer application (Figure 3c). Regarding the soybean cultivar factor, a higher incidence of pathogens was observed for ST 797 IPRO (Figure 3c). However, this did not affect the physiological quality of the seeds (Table 1). It is worth noting that, considering the market requirements, the indication of only a germination rate is insufficient, and other 
indications of vigor, such as seedling emergence, emergence rate index and seedling dry matter, are required (Zuffo et al. 2017a and 2017b). Thus, although the $\mathrm{N}$ levels resulted in lower pathogen incidences (Figure 3b), the application of this nutrient has only a small effect on the other variables evaluated. In this sense, it is possible to affirm that the supply of $\mathrm{N}$ did not improve the physiological quality of the seeds, under the conditions of the present study. The results are similar to those observed by Crusciol et al. (2003), who evaluated the effect of $\mathrm{N}$ on the physiological quality of common bean seeds. According to Ambrosano et al. (1996), the physiological quality depends on the attributes intrinsic to the seed, which determine its potential to generate a new plant, healthy and vigorous, whether grown under favorable conditions or not.

The fact that the $\mathrm{N}$ fertilizer application did not improve the physiological quality of the seeds may be due to the high $\mathrm{N}$ fixation ability of the Bradyrhizobium-soybean symbiosis, which supplied all the $\mathrm{N}$ that the soybean crop requires. Possibly, the amount of $\mathrm{N}$ fixed by the crop met the plant requirements, and supplementary fertilization with mineral $\mathrm{N}$ was not needed. Some studies have reported that the use of $\mathrm{N}$ fertilizers does not improve the productive performance of the crop (Aratani et al. 2008, Kaschuk et al. 2016).

Therefore, for these conditions, the choice of whether or not to apply N should be based on costs. Nitrogen fertilization in soybean crops should only be used where it is more economical for the producer to buy a formulated fertilizer, with $\mathrm{N}$ as part of its composition, as already recommended (Embrapa 2013) for the production of soybean grains.

\section{CONCLUSIONS}

1. The use of chemical $\mathrm{N}$ fertilizer associated with the inoculation of Bradyrhizobium japonicum bacteria did not prove to be a consistent response, in terms of the effects on the physiological quality of soybean seeds, although the incidence of pathogens was reduced;

2. Soybean seeds of the ST 797 IPRO cultivar present a higher physiological seed quality and a lower sanitary quality;

3. Climatic conditions at the harvest time affect the physiological and sanitary quality of soybean seeds.

\section{REFERENCES}

ABRANTES, F. L. et al. Nitrogen in cover and physiological and sanitary quality of millet seeds (Panicum miliaceum L.). Revista Brasileira de Sementes, v. 32, n. 3, p. 106115, 2010.

AMBROSANO, E. J. et al. Efeito do nitrogênio no cultivo de feijão irrigado no inverno. Scientia Agricola, v. 53, n. 2 , p. 338-342, 1996.

ARATANI, R. G. et al. Adubação nitrogenada em soja na implantação do sistema plantio direto. Bioscience Journal, v. 24, n. 3, p. 31-38, 2008.

BARRANQUEIRO, H. R.; DALCHIAVON, F. C. Aplicação de azoto na cultura da soja. Revista de Ciências Agrárias, v. 40, n. 1, p. 196-204, 2017.

BINOTTI, F. F. S. et al. Efeito do período de envelhecimento acelerado no teste de condutividade elétrica e na qualidade fisiológica de sementes de feijão. Acta Scientiarum Agronomy, v. 30, n. 2, p. 247-254, 2008.

BRASIL. Ministério da Agricultura, Pecuária e Abastecimento. Padrões para produção e comercialização de sementes de soja [Glycine max (L.) Merrill]. Instrução normativa $\mathrm{n}^{\circ} 45$, de 17 de setembro de 2013. Diário Oficial da União, Brasília, DF, 20 set. 2013. Seção 1, p. 29.

BRASIL. Ministério da Agricultura, Pecuária e Abastecimento. Regras para análise de sementes. Brasília, DF: MAPA/ACS, 2009.

CALISKAN, S. et al. The effects of nitrogen and iron fertilization on growth, yield and fertilizer use efficiency of soybean in a Mediterranean-type soil. Field Crops Research, v. 108, n. 2, p. 126-132, 2008.

CARVALHO, N. M.; NAKAGAWA, J. Sementes: ciência, tecnologia e produção. Jaboticabal: Funep, 2012.

CASTRO, E. M. et al. Physiological quality of soybean seeds produced under artificial rain in the pre-harvesting period. Journal of Seed Science, v. 38, n. 1, p. 14-21, 2016.

CHIBEBA, A. M. Co-inoculation of soybean with Bradyrhizobium and Azospirillum promotes early nodulation. American Journal of Plant Science, v. 6, n. 10, p. 1641-1649, 2015.

COMPANHIA NACIONAL DE ABASTECIMENTO (Conab). Acompanhamento da safra brasileira: grãos, décimo primeiro levantamento, agosto 2018. Brasília, DF: Conab, 2018.

CRUSCIOL, C. A. C. et al. Efeito do nitrogênio sobre a qualidade fisiológica, produtividade e características de sementes de feijão. Revista Brasileira de Sementes, v. 25, n. 1, p. 108-115, 2003. 
DANELLI, A. L. et al. Qualidade sanitária e fisiológica de sementes de soja em função do tratamento químico de sementes e no campo. Revista Ciencia y Tecnología, v. 4, n. 2, p. 29-37, 2011.

DOMINGOS, C. S. et al. Nutrição mineral e ferramentas para o manejo da adubação na cultura da soja. Scientia Agraria Paranaensis, v. 14, n. 3, p. 132-140, 2015.

EMPRESA BRASILEIRA DE PESQUISA AGROPECUÁRIA (Embrapa). Tecnologias de produção de soja: região central do Brasil 2014. Londrina: Embrapa Soja, 2013.

FELISBERTO, G. et al. Agronomic performance of RR soybean cultivars using two different presowing desiccation periods and distinct post-emergence herbicides. African Journal of Agricultural Research, v. 10, n. 34, p. 3445-3452, 2015.

FORTI, V. A. et al. Avaliação da evolução de danos por "umidade" e redução do vigor em sementes de soja, cultivar TMG113-RR, durante o armazenamento, utilizando imagens de raios $\mathrm{X}$ e testes de potencial fisiológico. Revista Brasileira de Sementes, v. 32, n. 3, p. 123-133, 2010.

FRANÇA-NETO J. B. et al. A importância do uso de semente de soja de alta qualidade. Informativo Abrates, v. 20, n. 1-2, p. 37-38, 2010.

FRANÇA-NETO, J. B. et al. O teste de tetrazólio em sementes de soja. Londrina: Embrapa, 1998.

KASCHUK, G. et al. Response of determinate and indeterminate soybean cultivars to basal and topdressing $\mathrm{N}$ fertilization compared to sole inoculation with Bradyrhizobium. Field Crops Research, v. 195, n. 1, p. 21-27, 2016.

KRZYZANOWSKI, F. C. et al. Vigor de sementes: conceitos e testes. Londrina: Abrates, 1999.

LOEFFLER, T. M. et al. The bulk conductivity test as an indicator of soybean seed quality. Journal of Seed Technology, v. 12, n. 1, p. 37-53, 1988.

MACHADO, J. C. Tratamento de sementes no controle de doenças. Lavras, MG: UFLa/FAEPE, 2000.

MARCOS-FILHO, J. Fisiologia de sementes de plantas cultivadas. Piracicaba: Fealq, 2005.

MARSCHNER, H. Mineral nutrition of higher plants. San Diego: Academic Press, 1995.
MCCOY, J. M. et al. Nitrogen fertilization of soybean affects root growth and nodulation on two soil types in Mississippi. Communications in Soil Science and Plant Analysis, v. 49, n. 2, p. 181-187, 2018.

MORENO, G. et al. Application of nitrogen fertilizer in high-demand stages of soybean and its effects on yield performance. Australian Journal of Crop Science, v. 12, n. 1, p. 16-21, 2018.

PETTER, F. A. et al. Respostas de cultivares de soja à adubação nitrogenada tardia em solos de Cerrado. Revista Caatinga, v. 25, n. 1, p. 67-72, 2012.

RAMALHO, M. A. P. et al. Experimentação em genética e melhoramento de plantas. Lavras: Ed. UFLa, 2012.

SEDIYAMA, T. Tecnologia de produção de sementes de soja. Londrina: Mecenas, 2013.

SILVA, A. S. et al. Adubação nitrogenada em soja: um estudo sobre potencial fisiológico de sementes. In: ALFARO, A. T. S; TROJAN, D. G. (Orgs.). Descobertas das ciências agrárias e ambientais 2. Ponta Grossa: Atena, 2017.

SOARES, I. O. et al. Interaction between soybean cultivars and seed density. American Journal of Plant Science, v. 6, n. 9, p. 1425-1434, 2015.

TOLEDO, M. Z. et al. Qualidade fisiológica e armazenamento de sementes de feijão em função da aplicação tardia de nitrogênio em cobertura. Pesquisa Agropecuária Tropical, v. 39, n. 2, p. 124-133, 2009.

ZAMBIAZZI, E. V. et al. Potassium fertilization and physiological soybean seed quality. Agricultural Sciences, v. 5, n. 11, p. 984-991, 2014.

ZUFFO, A. M. et al. Foliar application of Azospirillum brasilense in soybean and seed physiological quality. African Journal of Microbiology Research, v. 10, n. 20, p. 675-680, 2016.

ZUFFO, A. M. et al. Physiological and enzymatic changes in soybean seeds submitted to harvest delay. Pesquisa Agropecuária Tropical, v. 47, n. 4, p. 488-496, $2017 \mathrm{a}$.

ZUFFO, A. M. et al. Physiological and sanitary quality of soybean seeds harvested at different periods and submitted to storage. Pesquisa Agropecuária Tropical, v. 47, n. 3, p. 312-320, $2017 \mathrm{~b}$. 